【論 文】

\title{
中国における食品製造副産物の利活用システムに関する事例分析
}

ーりんごジュース製造副産物リサイクル・システムの日中比較研究一

\author{
泉谷眞実・房家垛・石塚哉史・松崎正敏（弘前大学）
}

\section{Case Study about the Utilization System of Food manufacturing by-product in China}

\author{
Masami IZUMIYA · Jiachen FANG • Satoshi ISHITSUKA • \\ Masatoshi MATSUZAKI (Hirosaki University)
}

The purpose of this paper is to clarify the characteristics and problems of the utilization system of apple pomace by comparing Japan and China.

In this paper, the following points were clarified.

Firstly, in China, apple pomace is dried and

\section{1. 問題状況と課題}

現在、中国は世界一のりんご生産国に成長し、 その生産量を背景としてりんご果汁の世界最大の 輸出国にもなっている。そこでは、ジュース生産 に伴う大量の製造副産物が発生している。

中国におけるりんごジュース製造副産物（以下 ではりんご粕と略）の処理をめぐっては、廃棄物 の処理に対する規制の強化、すなわち後述するよ うに 2004 年以降はりんご粕の生投棄が禁止され たため、中国のりんごジュースメーカーもりんご 粕の適切なリサイクルを求められるようになって いることが大きな変化としてあげられる。

他方、国際的な飼料価格の高止まりの中で、食 品製造副産物の飼料需要が增加しており、特に日 本では「エコフィード」としての利用が政策的に 推進されていることもあって、その飼料需要が高 まっている。

このような中国におけるりんご粕をめぐる新た な対応の必要性と飼料需要の増加を背景として、 日本においても安全性の面でこれまで躊躇されて いた中国からのりんご粕の輸入について、独自に 安全性を確認することで行う事例もみられ始め た。

連絡先：izumiya@cc.hirosaki-u.ac.jp（泉谷畺実） used as animal feed, but half of them discarded.

Secondly, in Japan, apple pomace is used as animal feed. In spite of part of that disposing of as industrial waste, it is imported from Chine. As a result, supply-demand mismatch has occurred in Japan.

このような輸入の動きが促進された場合、稲わ らにみられるように、国内資源は廃棄しつつ、同 時に中国から輸入を行うという状況がりんご粕の ような食品製造副産物でも進展するという「地域 における需給の不整合問題」（泉谷編〔3]）が搪 大寸る危険性がある。

以上のような問題認識から本論文では、中国に おけるりんご粕の利活用システムについて、実態 調査に基づいて、その現段階的な特徴を把握する とともに、日本との比較を行い、中国と日本のり んご粕利活用システムにどのような課題があるの かを明らかにしたい。

本稿で対象とする中国のりんご果汁製造に関す る既存の研究を見ると、石塚 [1]、山田〔6]等、 中国のりんごジュース産業に関する研究はこれま でも行われてきたが、副産物のリサイクルを視野 に入れた研究は行われていない。

そこで、中国の実態に関しては、中国のりんご 粕に関する統計データと国内最大のりんご生産量 をほこる陝西省で行ったりんごジュース加エメー カー 1 社の調査結果を用いた事例分析を行う。ま た、日本におけるりんご粕の利活用システムにつ いては青森県のりんごジュース加エメーカーを対 
象としたわれわれのこれまでの研究成果を用い、 りんご粕の輸入に関する赛態は国内の TMR セン ター 1 社の調査結果を用いる。このように、本 稿はあくまでも事例的な分析にとどまることをは じめに述べておきたい。

\section{2. 中国におけるりんごジュース加エとりんご粕}

中国は世界最大のりんご生産国であり、2010 年には世界のりんご生産量 6,957 万トンのうちの 半分近い 3,327 万トンを生産し、第 2 位のアメリ カの 421 万トンを大きく引き離している。この 生産量を背景に、りんごの「天然果汁」(浱縮果 汁とストレート果汁の合計）の輸出でも世界で最 も多く、2009 年には 80 万トンを輸出し、第 2 位のドイツ（31 万トン）の 2 倍以上におよぶ。 これに対して日本では、外国産のりんご果汁の輸 入量は 2010 年には 6 万 3,861 キロリットルであ り、このうちの 4 万 2,932 キロリットルを中国が 占めている (以上、青森県『平成 23 年産りんご 流通対策要項』による)。

より具体的な状況を LEADERSHIP 社 [7] か らみると、中国には主たる果汁会社が 5 社あり、 この上位 5 社で国内果汁市場の 7 割を供給して いる。2007 08 年度の鋠縮果汁生産量は 104 万トンであり、国内では果汁の需要が少ないため、 ヨーロッパ、アメリカ、オーストラリア、日本に 輸出されている。

2008 年の生りんご粕の発生量は、加工量の 30 $\%$ と仮定して約 120 万トンと推計している。図 1 をみると、生りんご粕の発生量は加工用りんご 数量の変動にあわせて 100 万トンから 200 万ト ンの間で変動している。このうち乾燥される粕が $91 \%$ と大部分を占め、ペクチン製造原料が $8 \%$ 、 堆肥と燃料になるのが 1 〜 $\%$ である。

りんご粕の乾燥加工会社は、把握できるのが 50 社で、小規模会社も含めれば 100 社と推定され ており、ペクチンの製造会社は 5 社である。

乾燥りんご粕は年間 30 万トン程度の産出量に なっている。乾燥りんご粕の飼料での需給は、需 要を供給が上回っているため、利用率は 4 割程 度であり、15〜20 万トンの乾燥りんご粕が廃棄 されているという。

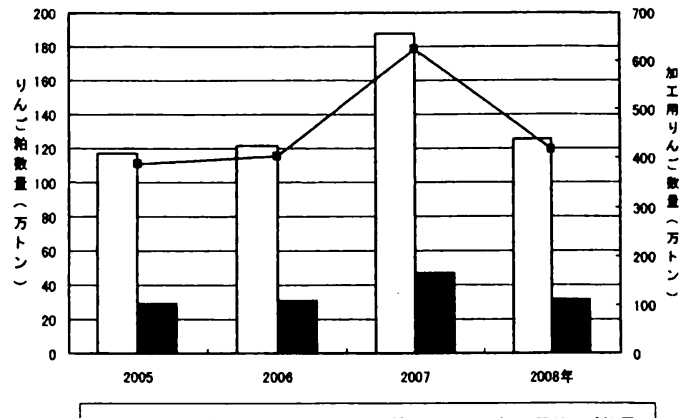

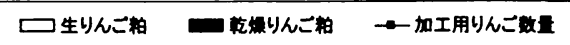

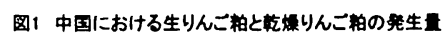

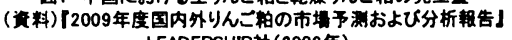
LEADERSHIP杜(2009年)。

以上のように、中国のりんご粕は 9 割が乾燥 処理されており、それによって輸送・保管が容易 になるため乾燥粕は飼料としての利用が進んでい るが、他方で、その半分が廃棄されるのが現状で あり、供給過剩状態にある。

\section{3. 中国におけるりんご粕の利活用システムの実態} つぎに、2009 年 12 月に中国最大のりんご産 地である陝西省の西安市に本社があるりんごジュ ース加エメーカー A 社で行った聞き取り調査結 果から、りんご粕の利活用システムの実態につい てみていきたい。

\section{(1) 陝西省·A社の事例}

調査を行った A 社は、りんごとナシのジュー ス加エメーカーである。まず、本社事務所での聞 き取り調査結果からみていこう。

$\mathrm{A}$ 社の搾汁工場は陝西省、甘肃省、山西省およ び寧夏回族自治区の 4 省・区に 8 工場あり、1工 場で季節雇用が 100 人程度行われている。

A 社がりんご粕のリサイクルを始めた背景に は、政府による規制の強まりがある。具体的には、 中国では環境保全の面から、法律でりんご粕をそ のまま処分するのは禁止されており、政府は全て のジュース工場に搾り粕を乾燥するよう呼びかけ ている（ただし、乾燥機導入に対する国の補助等 はない)。この規制は 2004 年頃から厳しくなり、A 社では同年から搾り粕の乾燥機を導入している。 $\mathrm{A}$ 社では、それ以前にはそのまま放棄していたた め、りんご粕が腐敗して水分が地下に浸透し、悪 
臭が発生していた。このような環境污染の発生と 政府の指導が、第 2 節でみたりんご粕の乾燥割合 の高さに結びついている。

$\mathrm{A}$ 社では、原料りんごを陝西省と山西省から調 達している。西安市では年によって雱の被害があ り、その際には加工用りんごが大量に発生してい る。また、8 月から翌年の 2 月までりんごを搾汁 し、同じ時期に搾り粕を乾燥しているため（この 時期以外は工場は休業している)、りんご粕の発 生には季節性が存在する。なお、農薬の散布状況 が把握出来ない産地の原料りんごは使用していな いため、りんご粕の安全性は、原料の面からは担 保されている。

生産されたジュースは殺菌後に全てドラム缶に 入れられて冷凍保存され、その $90 \%$ 以上は輸出 されており、輸出先はヨーロッパのみである。原 料リンゴの購入価格や仕入れ方法、ジュースの輸 出先は社内の全工場共通で行われている。

りんご粕は、(1)乾燥した状態で販売するものと、 (2)粉状に加エし、 $20 \mathrm{~kg}$ の袋に詰めて利用するも のがある。また、ナシの搾り粕は圧縮しやすいた め、ペレット化し、乳牛の飰になっている（ナシ の粕の嗜好性はりんごよりも高いという)。現在 はりんご粕の全てが飼料として出荷されている が、将来はペクチン原料として利用したいと考え ている。

りんご粕は乾燥して利用されるが、乾燥工場は 石炭を燃料としており、粕の最大発生量を基準に 作られているため、乾燥能力は粕の発生量に対し て十分存在するという。りんご粕は送風で乾燥し ているため、エネルギーが多く必要であるという 問題がある。100kg の加工用りんごから $25 \mathrm{~kg} の$ 搾り粕が発生し、生粕 $5 \mathrm{~kg}$ から乾燥りんご粕が $1 \mathrm{~kg}$ 生産される。

りんごの乾燥費用は乾燥粕 1 トン当たり 900 元（日本円で 1 万 3000 円）で、販売価格は年に よって 200 元程度の変動があるが、最近では 1 トン当たり 800 元（1 万 2000 円）程度である。 乾燥を行わなければ罰金を支払わなくてはならな いために、利益を度外視しても必要な作業である という。

乾燥粕は中国全土に販売しているが、主に中国
の南部に 9 割が乳牛の餌として出荷され、一部 は淡水魚の眲として利用されている。多くの酪農 経営と直接取引を行っており、大量に購入したユ ーザーには割引販売も行っている。

ただし、前述のように中国全体の乾燥りんご粕 の利用率は 4 割程度であるため、 $\mathrm{A}$ 社の場合も出 荷された乾燥りんご粕が現害に全て飼料として利 用されているかどうかは不明である。

本稿での主要な関心の一つである乾燥りんご粕 の輸出については現在は行っていないが、日本で まとまった数量の購入を希望するのであれば、り んご粕の販売は可能であるとのべていた。

\section{（2）陝西省·A社加工工場の実態}

つぎに、陝西省にある $\mathrm{A}$ 社の加工工場での聞 き取り調査結果をみていきたい。

この加工工場は 1997 年に設置されており、1 日 800 トンの原料りんごを搾汁する能力がある。 中国国内には 1 日 2,000 トン規模の搾汁能力をも つ工場もあり、この工場は規模が小さいといえる。

調査を行った 2009 年には 6 万トンの原料りん ごを加エしているが、平年では 8 〜 12 万トンの 幅でりんごの㵠汁量は変動している。2009 年に はヨーロッパ市場との関係でジュース価格が安か ったため、あまり搾らなかったという。このよう に、りんごの搾汁数量の年次変動があるため、り んご粕の供給量も年によって変動していることに なる。

3 台のトラックで生粕をジュース工場から乾燥 工場に運び、石炭の燃焼による熱風で乾燥を行っ ている。1 日に発生した粕はその日のうちに乾燥 するのが基本だが、発生量には日別の変動もある ため、実際には $2 \sim 3$ 日分をまとめて乾燥し、 燃料となる石炭が無駄にならないように効率化を はかっている。

この工場での乾燥粕の販売先は農家がほとんど で、農家が買いに来る場合と、運送料を別にもら って配達する場合があり、その場合の運貨は $1 \mathrm{t}$ 当たり $0.4 \sim 0.5$ 元（6〜8 円）である。工場ま で自家用トラックや三輪車で直接りんご粕を買い に来る農家もいる。

また、りんご粕の販売地域は中国国内全域に広 
がっているが、この工場が立地する陝西省内は酪 農経営が少ないために需要も少なく、省外の酪農 地帯での需要が多くなっている。遠くは新疆ウイ グル自治区の農家まで販売しており、浙江省、広 東省へも販売している。これらはいずれも中国の 酪農生産地帯である(李〔5])。

\section{4. 日本におけるりんご粕の利活用システムと 輸入りんご粕利用の実態}

つぎに、日本におけるりんご粕利活用システム を青森県の事例から検討し、輸入りんご粕利用の 実態をK・TMR社の事例から検討したい。

(1) 日本のりんご粕利活用システム (泉谷 [2] [3])

日本における搾汁りんご数量は、2010 年のり んご収穫量の $12 \%$ であり、青森県は搾汁数量の $67 \%$ を占めている（青森県『平成 23 年産りんご 流通対策要項』による)。りんご粕はりんごジュ 一ス加工量とほぼ比例して発生するため、全国で 発生するりんご粕の 7 割が青森県で発生してい ると推定される。

図 2 には、青森県におけるりんご粕の発生量と 用途を示した。ここでの特徵は、中国と同様にり んご粕供給量の年次変動が存在することである。 2000 年以降の発生量をみても、少ないときには 1 万トン、多い時では 2 万 5,000 トンまで増加して いる。この変動は、加工用仕向りんご数量の変動 に対応している。また、中国と同様にりんご粕の 発生は季節的に集中しており、日本ではりんごが 収穫される以降の 10 月〜 12 月に集中している。

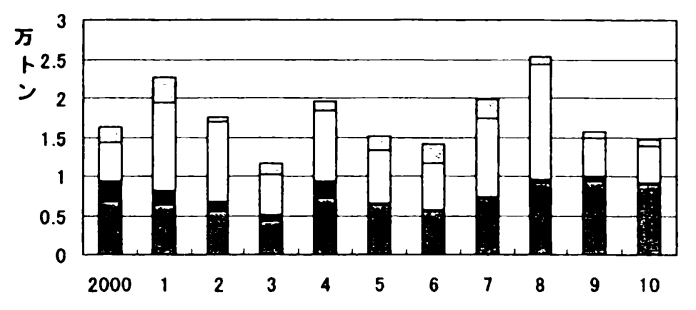

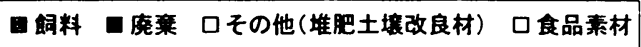

図2青森県におけるりんこ柏の発生量と用途 (資料)肓森県『しんご流通対策要項】。

りんご粕のリサイクル利用では、飼料化と堆肥
化が主要な用途となっている。また、用途間の関 係では、焼却、堆肥化、飼料化の順でコストが低 くなるため、排出事業者としては飼料化を最も優 先すべき用途として考えている。

飼料用では、りんご粕は袋や容器にそのまま詰 める「生粕利用」となっている。りんご粕は容器 の中で自然発酵し（アルコール発酵）、1 年間程 度の保存が可能になる。この点が中国と最も異な る点であり、水分含有率が高いため、輸送コスト が高く、保管にも限界がある。

図 2 から飼料化数量をみると、2000 年から 2007 年まではおよそ 6,000 トンで安定している が、飼料価格が高騰した 2008 年からはその量が 1 万トンに恒常的に増加している。

以上のように、日本のりんご粕利活用システム においては飼料需要が増加しているが、「生粕利 用」のために保管や輸送に制約が発生しているの が現状である。また、平年では三分の一程度が堆 肥として低利用の状態になっている。

(2) 輸入りんご粕利用の実態 $-K \cdot T M R$ 社の事例一

つぎに、2010 年に行った K・TMR 社の調査結 果をもとに、輸入りんご粕利用の実態についてみ ていきたい。

$\mathrm{K} \cdot \mathrm{TMR}$ 社は 1999 年に設置され、2000 年に TMR センターを設置している。TMR（Total Mixed Rations:混合飼料) は、そのまま給餌する 完成品と追加の加工が必要な食品残さだけのもの の 2 種類を生産している。年間 1 万トン弱の食品 残さを集荷し、1 万 5,000 トンのウェット飼料を 生産している。飼料の供給先は、近隣を含む 6 県にわたり、全て酪農家が使用している。

飼料の原料は、稲わらの他、キノコ菌床粕が多 く、酱油粕、おから、いも焼酎粕、麦わらも使用 している。ビール粕は発泡酒への消費の移行によ って手に入りづらくなっているという。また、原 料の調達に関しては、近隣に工場が立地し、容易 に入手可能なものを利用するのが基本であると考 えている。そのため、後述のようにりんご粕が必 要であっても、りんごジュース工場が近隣に存在 しないために輸入原料を使用していると考えられ る。 
$\mathrm{K}$ ・TMR 社では、国内産のりんご粕は使用し ていないが、中国製の乾燥した製品であるりんご 粕ペレットを 2009 年から使用している。りんご 粕は整腸郕としての位置づけであり、1 ケ月にお よそ 70 トン、年間 1000 トンの利用である。中 国からのりんご粕ペレットの調達は商社まかせに せず、自社の社員が現地に赴いて品質をチェック している。コンテナでのバラ輸送であり、以前は 木くずが混じっていたという問題もあったが、現 在は大きな問題はないという。日本国内の運賃が 高いため、水分が少なく、単位重量当たりの栄養 分が多いペレットのメリットは大きいという。

以上のように、国内においても安全性に配慮し つつ、中国からのりんご粕の調達が進められてい るのである。

\section{5. りんご粕の輸入可能性に関する定量的比較}

以上のように、りんご粕の中国における大量供 給と日本における食品製造副産物への需要増加の もとで、中国から日本へのりんご粕の輸出条件が 生まれてきている。つぎに、その経済的条件とな る日本と中国のりんご粕の数量と価格を整理した 表 1 から、その可能性について定量的にみていき たい。

まず、生粕換算で、中国では日本の 60 倍のり んご粕が発生しているが、日本の発生量の 30 倍 にあたるりんご粕が廃棄されている。また、 $\mathrm{K} ・$
TMR 社の 1 社で日本のりんご粕の四分の一に相 当する数量が中国から輸入されている。このよう に、飼料ユーザーが本格的に利用を始めた場合に は、国内で発生するりんご粕だけでは不足する状 態になっている。しかし、他方で青森県では生換 算で 5,000 トンが堆肥として処理されており、こ れは $\mathrm{K} \cdot \mathrm{TMR}$ の利用量とほぼ同量となってい る。

つぎに、価格をみると、青森県のりんご粕はぺ レットに加工した場合、ウサギ飼料用の事例では 1 トン当たり 315 万円となっている（ただし、実 際の販売は $100 \mathrm{~g}$ 単位で行われており、大量取引 の場合にはより低い価格が設定されていると考え られる)。国内でのりんご粕の乾燥コストが非常 に高いために小売価格が高くならざるを得ないの である。

これに対して、日本国内での中国産りんご粕ぺ レットの小売価格は輸入商社の事例では 1 トン 当たり 4 万 1,000 円となっている。日本国内では、 国産ペレットが中国産ペレットの $70 \sim 80$ 倍程 度の価格になっている。

また、2013 年に行った A 社への補足調査では、 乾燥りんご粕の中国国内での販売価格は低迷して おり、これに対して日本への輸出価格は高いこと から、輸出にメリットがあることを指摘している。

以上のような価格関係と数量関係を踏まえれ ば、乾燥することによって安定的に確保が可能で、

表 1 りんご粕の数量と価格

\begin{tabular}{|c|c|c|c|c|c|}
\hline & \multicolumn{2}{|c|}{ りんご粕数量 $(\mathrm{t})$} & \multirow{2}{*}{$\begin{array}{l}\text { 廃粪量 (堆 } \\
\text { 肥化含む) } \\
\text { (生換算) }\end{array}$} & \multirow{2}{*}{$\begin{array}{l}\text { 乾燥りんご } \\
\text { 粕価格 }\end{array}$} & \multirow[t]{2}{*}{ 価格データ } \\
\hline & 生 & 乾燥 & & & \\
\hline 中国計 & 120 万 & 24 万 & 72 万 $\mathrm{t}$ & - & - \\
\hline$A$ 社陝西省工場 & 1 万 5000 & 3000 & 不明 & 1 万 2000 円 $/ \mathrm{t}$ & $\mathrm{A}$ 社陝西省工場のデータ \\
\hline 日本計 & $\underline{2}$ 万 & 4000 & 不明 & - & - \\
\hline 青森県 & 1 万 5000 & 3000 & $5000 \mathrm{t}$ & $\begin{array}{l}315 \text { 万円 } / \mathrm{t} \\
(100 \mathrm{~g} \text { 袋 })\end{array}$ & $\begin{array}{l}\text { 青森県のりんご粕を使用したペット用ペレットで、 } \\
\text { 小売価格の事例 }\end{array}$ \\
\hline $\begin{array}{l}\mathrm{K} \cdot \mathrm{TMR} \text { 輸入 } \\
\text { 量 }\end{array}$ & 5000 & $\underline{1000}$ & & $\begin{array}{l}4 \text { 万 } 1000 \text { 円 } / \mathrm{t} \\
(20 \mathrm{~kg} / \text { 袋 })\end{array}$ & $\begin{array}{l}\text { 中国から輸入のりんご粕ペレットの価格は、別の } \\
\text { 商社の事例データ }\end{array}$ \\
\hline
\end{tabular}

（資料）事例調查結果、LEADERSHIP 社 [7]他。

（注 1) 生りんご粕と乾燥りんご粕の重量換算率は、5：1で推計した。

2）りんご粕数量は、下線部を引いた数值が原データで、その他は換算値。 
輸送コストも低く、かつ相対的に価格が安い中国 産りんご粕ペレットへの日本での需要は、安全性 の問題がクリアされれば增加すると考えられる。 前述のように、A社では農薬の散布状況が把握出 来る産地の原料りんごしか使用していないため、 原料段階での安全性は確保されつつあり、輸入の ハードルは低下している。

\section{6. おわりに}

最後に、中国におけるりんご粕の利活用システ ムの現段階的な特徴を整理し、中国と日本の利活 用システムの課題について考察を行いたい。

まず、中国におけるりんご粕の利活用システム の現段階的特徵をみると、食品廃棄物の投棄によ る環境污染の発生を背景として、この 10 年の間 に政府による環境規制とリサイクルの推進が進め られてきた。そして、りんごジュースメーカーは その規制をクリアするために、利益を度外視して もりんご粕の乾燥を行ってきており、その結果と

してりんご粕の乾燥割合が高まっていた。

中国でも日本と同様に、供給量の年次変動と季 節的な集中が存在していたが、りんご粕を乾燥す ることによって保管が可能になり、これらの供給 変動に対応することが可能となっていた。また、 乾燥することによって輸送コストが削减でき、長 期間の保管も可能となるため、中国国内での広域 的な飼料流通が進められることになった。このこ とは輸出を行うための強力な条件になる。

中国におけるりんご粕利用の課題としては第 1 に、このようなりんご粕の乾燥が可能な背景には、 豊富で安価に存在する石炭への依存度が高い中国 特有の要因が存在するが（郭 [4]）、温室効果ガ スの発生抑制が必要となってくる点が課題として あげられる。第 2 に、乾燥粕の半分が廃棄され る状況になっており、資源の有効利用が課題であ る。

これに対して日本の利活用システムでは、りん ご粕の飼料利用が多く、飼料価格の高止まりの中 でその量は增加していた。しかし、三分の一は堆 肥化という形で低利用の状況になっていた。また、 国内では低利用の状況なのにもかかわらず、事例 企業ではりんご粕の中国からの輸入が行われてい
た。このように、日本の利活用システムの課題と しては、国内では少なくない割合が低利用の状態 になっているにもかかわらず、中国からの輸入が 行われるという形で、バイオマス利用の「地域に おける需給の不整合問題」が発生していることが あげられる。

そして、中国におけるりんご粕の供給過剩と日 本における低価格なりんご粕の飼料需要の拡大を 背景にして、日本ではりんご果汁の輸入を行うだ けにとどまらず、りんご粕の輸入も進められてい くベクトルが強く存在するのである。

しかし、地域資源としてのバイオマスの利活用 システムを考える場合、地域内や国内での利用が 優先されるべきである。そのため、中国と日本に 共通する課題としては、堆肥化や廃棄される部分 をそれぞれの国や地域で有効活用を促進するため の方策の検討が最優先にあげられる。

引用文献

〔1〕石塚哉史「華東地域の日系食品企業における企 業戦略と対日輸出の実態一山東省・浙江省の事 例を中心に一」『農村研究』第 99 号、2004 年。

〔2〕泉谷道実「農業資材市場之静脈産業」『農業市場 研究』第 19 巻第 3 号、2010 年。

〔3〕泉谷真実編著『エコフィードの活用促進』農山 漁村文化協会、2010年。

〔4]郭四志『中国エネルギー事情』岩波書店、2011 年。

（5）李勝利「中国奶牛業的状況及発展趨勢」（中文） 『中国畜牧雑誌』44、2008 年。

（6）山田七絵『グローバル化と途上国の小農』アジ ア経済研究所、2007 年)。

[7] LEADERSHIP 社『2009 年度国内外りんご粕 の市場予測および分析報告』（中文）2009 年。

〔2013 年 4 月 15 日受理〕 